\title{
Sustainable Regional Development in Albania and the Challenges to European Integration
}

\author{
European University of Tirana \\ Email: Iuljeta.minxhozi@uet.edu.al
}

Alma Marku, PhD Cand.

alma_marku@yahoo.com

\section{Doi:10.5901/ajis.2015.v4n1s1p27}

\section{Abstract}

\begin{abstract}
Minimizing or eliminating regional disparities is one of the priorities and challenges of the governments nowadays. Regional disparities are characteristic of large countries, but mostly of developing countries. Studies have shown that these disparities are two to six times more than in developed countries. Using different approaches to eliminate disparities, governments attempt to help economic activities of certain regions in order to be more competitive. In this paper, firstly I will conduct a theoretical and empirical assessment of the regional development approach as per se. The purpose of analyzing the theoretical approach is to introduce the differences between the early approaches of developing the infrastructure and attracting inward investments in the different regions of the country with the latest one of effectively using the public recourses and significantly better policy outcomes. This approach includes some measures to increase the competitiveness among the regions of the country. Secondly, in the paper I will observe the approach followed by European Union and especially focus on the Albanian government approach to address the inequality of regions in Albania. The purpose of this analysis is to understand if regional development policies, legal and institutional framework put in place by the government, are consistent with those of the community in which Albania wants to join in, the European Union. The analyzes will show that there are some adjustments that Albania has to do in its regional development policy and legal and institutional framework in order to benefit from the financial instruments that European Union gives to candidate countries, in the process of the European integration.
\end{abstract}

Keywords: regional development, integration, government, legal framework, strategy

\section{Introduction}

Regional development is one of the priorities for governments all over the world. Studies have shown that regional disparities are attributes not only of large countries but also developing countries (Shankar \& Shah 2003, 2008). These studies indicate that these disparities are two to six times more than in developed countries.

In this paper I will analyze the early and the new approach on regional development. We will see that the early regional development policies which tended to try to minimize or eliminate disparities by developing the infrastructure and attracting inward investment of a region has led to that of effectively using the public resources. Then I will review the European Union approach to minimize regional disparities, taking into consideration that this is one the largest region that has put an emphasis on this subject. This review will led to the analyses of the Albanian case in her attempts to gain the full membership into the European Union.

In the last section I will include the findings and recommendations which may serve for other studies in the future.

\section{Theoretical Framework}

During these last years, governments of the countries have used different approaches to address the issues of regional developments. For sure, some of them have been successful and some not. Nevertheless, these approaches have raised some questions regarding the role that the government should have while implementing regional policies (Shankar, Shah, 2009).

These questions have to do with the role of the government such as: should it be a regulatory policy in order to develop policies to help poor regions to implement policies which may enhance the competitiveness among the regions by creating a free market.

According to Shankar and Shah (2009) these questions have to do with the nature of the regional developing 
policy. Should it be a regulatory approach using different economic tools to minimize the differences among the regions, or it should create a free common market and remove internal barriers for goods and people? The second question has to do with the distribution of power among the central and local government. Should it be the central government that decides what is the best distribution of public funds for the regions, or should local government develop its region with its own economic activities?

\subsection{Early Approach}

As we mentioned above, regional development is concerned with reducing regional disparities by supporting economic activities in regions (OECD definition). This include those economic activities that increase employment and of course those activities that generate wealth for population.

According to the early approach, governments tried to achieve these objectives by implementing regional development policy with the focus on development of the wide range infrastructure and inward investment.

Studies and research have shown that the past policies have failed to reduce regional disparities in a significant way. These policies have not been able to help the poorest regions, which have been left behind to catch up with the richest and the most developed ones, despite the allocation of significant public funds.

\subsection{The New Approach}

While the early approach was proved to be not so much effective in addressing the regional disparities a new approach to regional development is emerging (OECD). This approach promises more effective use of public resources and significantly better policy outcomes. The new approach is much more in favor of measures to increase the competitiveness of all regions.

Some key features of this new approach to regional development include: a strategic concept or development strategy that covers a wide range of direct and indirect factors that affect the performance of local firms; a focus on endogenous assets, and less on exogenous investments and transfers; an emphasis on opportunity rather than on disadvantage; a collective/negotiated governance approach involving national, regional and local government plus other stakeholders, with the central government taking a less dominant role ${ }^{1}$.

Nowadays researches show that in order to have real results on the field of regional policy we need to put in place crosscutting frameworks and strategies and also multi-level governance mechanisms. The challenge is to find the right balance between the different levels of government to use better their capacities, consequently more effective public policy outcomes.

In these two last decades, multi-level governance which can be understood as the exercise of authority and the various dimensions of relations across levels of government has changed. In particular, decentralization has made local and regional governments more powerful and supposedly increased their capacity to formulate and deliver policy. Local and regional governments, concerned that their economies are increasingly exposed to global competition, now expect to influence public policies so that they have a real and positive impact on improving the competitiveness of the regional economy and the well-being of residents. These trends have made governance of public policies both more complex and more demanding, involving multiple actors (public but also private) and requiring a rethinking of how central and subnational governments should collaborate (OECD).

\section{European Union Regional Policy}

Since the creation of the European Union, reduction of regional disparities has been a main concern (EC 2004a). In its history, EU has created different funds for member states, such as sector-based funds, regional funds and structural funds and later on cohesion funds to support this objective. Nevertheless, only in the late 80s significant changes leading to allocations for regional development has been made, by introducing the cohesion policy to neutralize the differences between the southern countries and others less favored regions operating in one single market.

Other changes were made with entering into force in 1993 of the Treaty of European Union. These changes have putted cohesion as one of the main objectives despite economic and monetary union and one single market. European

\footnotetext{
${ }^{1}$ http://www.oecd.org/gov/regionaldevelopment/regionaldevelopment.htm
} 
Union allocated one-third of its budget to cohesion policy for the period 1994-1999. Another major step on the side of the cohesion policy was made on the next planning period (2000-2006), in which European Union allocated $40 \%$ of its budget to the structural funds.

In 1999, European Council adopted the regional policy of European Union, which consists of reforming a number of policies and re-establishing four structural funds:

- The European Regional Development Fund, which invests in infrastructure and employment;

- The European Social Fund, which supports programmes to integrate the unemployed or disadvantage groups;

- The Guidance Section of the European Agricultural Guidance and Guarantee Fund to support farmers and programmes for the rural development;

- The Financial Instruments for Fisheries Guidance, which support the modernization of the fishing fleet.

Most of the structural funds go to support regions that are not in the same socio and economic development level than the rest of Europe (regions with a GDP per capita of less than $75 \%$ of the community average).

In the EC 2004 report it is mentioned that the process of deciding on the allocation of the regional funds is a process in which regional and national governments and European Commission interact with each other. European Commission is the responsible institution for preparing the budget distribution and decides on the rules and policies for the planning period, while the Council of Ministers and the Parliament review and approve the policy. After the approval, the budget is divided to the member states according to the recommendation of the European Commission for each objective. At this stage, member states or region prepare the regional plans and after taking the approval of the European Commission these plans are translated into projects and actions.

\section{Albanian Regional Policy}

\subsection{Policy and Legal Framework}

Albania has finalized the Stabilization and Association Agreement with European Commission on 12 June 2006. This agreement entered into force on 1 April 2009, which gave us the potential candidate status and to profit from the contribution of the first (capacity building) and second (cross-border cooperation) components of Instrument of Pre Accession (IPA). On 28 April 2009, the Government of Albania applied for the candidate status in the European Union. On 2010 and 2011 the European Commission's decision concerning the application of Albania was negative, because according to them the country has not reached the level required to comply with the accession criteria. Albania is working on 12 priorities set out from the European Commission. Gaining the candidate status, Albania should be able to benefit from three other components of IPA (regional development, human capacity building and rural development).

While still working on the criteria set out form European Commission to receive the candidate status, Albania has undertaken a number of its initiatives to address the phenomenon of regional development such as:

Adoption of the National Strategy for Regional Development 2007-2013, which aims at "A sustainable and balanced socio-economic growth between the regions of Albania, in general, and mountainous and remote areas in particular, in order to support the rapid development of the whole country and accelerate the process of integration into European Union and NATO membership".

According to the strategy, there are two strategic objectives that will enable sustainable and balanced growth through the regions of the country:

1. Counties are able to contribute to the sustainable development and competitiveness - and thus reduce social and economic disparities across the country. This will be achieved through the implementation of two programs: the National Programme for Regional Development and Program Development of Disadvantaged Areas.

2. The creation of an efficient management framework for regional development, through the drafting of the Law on Regional Development and the development of necessary institutional structures to manage policies for regional.

Regional Development Draft-Law aims to determine the objectives, principles, instruments and institutional framework for the management of regional development and promote balanced regional development in the Republic of Albania.

Economic development of communes, municipalities and regions, should not be seen as a separate problem or as an issue of the local authorities, but rather than an issue that is directly related to economic development at the national level, establishment of an encouraging climate for business through investment in infrastructure and the fight to reduce 
poverty. To encourage the development of smaller unit such as commune, municipality and county it is necessary to harmonize national budgetary policies with local ones. In view of this philosophy, it is necessary to integrate the sectorial policies of the central government at the regional level. In order to focus the budget policy on local and regional development problems, combating poverty and avoiding maximum fragmentation of the budget, the government established a fund called "Regional Development Fund".

According to the government, this policy is a preparatory exercise for the regions, in order to prepare them to be able in the near future, to apply for structural and investment funds from the European Commission. In addition, this policy will encourage local communities, institutions, and Albanian politics to carry out an administrative reform aimed at increasing the local units and their transformation into larger units and with better potential absorption of funds, thus enabling them to carry out their investment funds, those of the state budget and EU funds.

\subsection{A Picture of Regional Inequalities in Albania}

In order to address the existing inequalities in the regions, the government should have better recognition of social and economic differences among them. This will help the government to choose necessary political and financial instruments to address the issues of regional development.

In this context, European Commission and UNDP are supporting the Government in its attempt to minimize regional inequalities. In this regards, a study of regions inequalities (2009-2010) was prepared pain attention on five main axes: economy, demographics and spatial development, social cohesion, sustainable development and access to infrastructure, and finally local finances. Different indicators were selected and comparisons were made through districts and municipalities. Regarding the development gap in relation to the EU and other countries, were observed inequality as per GDP per capita (10\% of the GDP of the EU 27) and very high employment rate in agriculture (about $45 \%$ of the population country). Also the report points out that the country has very high difference between the developed pole, where Tirana (the highest regional development index 151) and Durres are the more developed regions and the less developed regions are Dibra and Kukes (the lowest regional index 75).

Bearing in mind these differences important policies may derive such as: implementation of specific local development plans; municipalities or communes with lower economic performance and acute social problems should be offered development assistance or different incentives. While rural development or social inclusion, should be addressed through other more specific interventions.

\section{Conclusions}

The analysis of the entire system by which Albania addresses regional development in the context of European Union requirements, reveals the lack of strategic orientation of regional development policies. Bearing in mind the timeframe and human and financial capacities it is necessary for the government to merge the actual institutional, legal and policy framework with that required by the European Union. Afterwards, the government can review the political framework of the regional development, according the recommendations of the European Commission by using the actual structures experience. In this regards, the focus might be the capacity building of the existing structures in local and central level.

In the sum, the experience of European Union regional development policies suggests the following lessons:

- Merging the actual institutional structures, with those suggested by the European Union;

- Taking advantage of the actual structures to review the national regional development policy framework;

- Capacity building of the regional and local level in order to develop their regional and local plans, and be able to profit from IPA funds;

- Clear definition of roles and responsibilities of central, regional and local government (approval of the regional development law);

- A better strategic and coherent distribution of the Regional Development Fund;

- Different and specialized projects for remote and undeveloped areas;

\section{References}

Bachtler, J and Michie, R., 1997. The Interim Evaluation of EU Regional Development Programmes: Experiences from Objective 2 Regions. Regional Studies, 31(9), pp. 849-858. 
Boldrin, M. and Canova, F., 2001. Inequality and Convergence in Europe's Regions: Reconsidering European Regional Policies. Economic Policy: A European Forum, (32), pp. 205-245.

Carrington, A., 2006. Regional Convergence in the European Union: A Stochastic Dominance Approach. International Regional Science Review, 29 (1), pp.64-80.

Shankar, R. and Shah, A., 2003. Bridging the Economic Divide within Countries: A Scorecard on the Performance of Regional policies in Reducing Regional Income Disparities. World Development. 31(8), pp. 1421-1441.

Shankar, R. and Shah, A., 2008. Regional Income Disparities and Convergence: Measurement and policy Impact Evaluation. In Anwar Shah, editor, Macro federalism and Local Finance, Chapter 4:143-192.Washington, DC: World Bank.

Martin, P., 1998. Can Regional Policies Affect Growth and Geography in Europe? World Economy, 21(6), pp. 757-774

World Bank (2008). Reshaping Economic Geography, World Development Report, 2009. Washington, DC: Oxford University Press for the World Bank

World Bank (2002), Expenditure Policies Towards European Union Accession.

Barca, F., (2009), an Agenda for a Reformed Cohesion Policy

www.eurada.org/site/files/Regional\%20development/Barca_report.pdf.

OECD, (2009), How Regions Grow. www.oecd.org/publications/Policybriefs

European Commission, (2010), EUROPE 2020, A Strategy for smart, sustainable and inclusive growth, Brussels.

European Commission and UNDP ISD Project, (2010), Towards a Revised Regional Development Policy Framework for 2010-2020.

McClements, C, (2010), Cross-cutting strategy for regional development Albania, Review

European Commission, (2009), Albania 2009 progress report.

Marinov, V., D. Malhassian, (2002), Measuring and assessment of disparities and their policy implications: the case of Bulgaria.

European Commission, 2004b. Third report on economic and social cohesion - COM (2004) 107 of 18 February 2004. Luxembourg: Office for Official Publications of the European Communities.

European Commission and UNDP ISD Project, (2010). Regional Disparities in Albania.

An inventory of local capacity for regional development in Croatia, (2009), CARDS 2004 "Regional Development Capacity Building Facility" (EUROPEAID/123369/C/SER/HR) Commission Regulation (EC) No 718/2007, (2007).

Implementing Council Regulation (EC) No 1085/2006, Establishing an instrument for pre-accession assistance (IPA). http://eurlex.europa.eu

European Union Regional Policy - working for the Regions. www.Publications.eu.int

European Council (1999), Presidency Conclusions, European council. 24 and 25 March 1999, available at www.inforegio.cec.eu.int

Eurostat (2000a), Statistics in Focus, Economic and Finance, Theme 2, European Union FDI with Candidate Countries: an Overview, $26 / 2000$ 
